\title{
Identification of Isolates that Cause a Leaf Spot Disease of Brassicas as Xanthomonas campestris pv. raphani and Pathogenic and Genetic Comparison with Related Pathovars
}

\author{
J. G. Vicente, B. Everett, and S. J. Roberts
}

First and second authors: Warwick HRI, The University of Warwick, Wellesbourne, Warwick CV35 9EF, UK; and current address of third author: Plant Health Solutions, 20 Beauchamp Road, Warwick CV34 5NU, UK.

Accepted for publication 21 February 2006.

\begin{abstract}
Vicente, J. G., Everett, B., and Roberts, S. J. 2006. Identification of isolates that cause a leaf spot disease of brassicas as Xanthomonas campestris pv. raphani and pathogenic and genetic comparison with related pathovars. Phytopathology 96:735-745.

Twenty-five Xanthomonas isolates, including some isolates received as either X. campestris pv. armoraciae or pv. raphani, caused discrete leaf spot symptoms when spray-inoculated onto at least one Brassica oleracea cultivar. Twelve of these isolates and four other Xanthomonas isolates were spray- and pin-inoculated onto 21 different plant species/cultivars including horseradish (Armoracia rusticana), radish (Raphanus sativus), and tomato (Lycopersicon esculentum). The remaining 13 leaf spot isolates were spray-inoculated onto a subset of 10 plant species/cultivars. The leaf spot isolates were very aggressive on several Brassica spp.,

several Brassica spp. and radish cultivars, the leaf spot isolates were divided into three races, with races 1 and 3 predominating. A differential series was established to determine the race-type of isolates and a genefor-gene model based on the interaction of two avirulence genes in the pathogen races and two matching resistance genes in the differential hosts is proposed. Repetitive-DNA polymerase chain reaction-based fingerprinting was used to assess the genetic diversity of the leaf spot isolates and isolates of closely related Xanthomonas pathovars. Although there was variability within each race, the leaf spot isolates were clustered separately from the $X$. campestris pv. campestris isolates. We propose that $X$. campestris isolates that cause a nonvascular leaf spot disease on Brassica spp. should be identified as pv. raphani and not pv. armoraciae. Race-type strains and a neopathotype strain for X. campestris pv. raphani are proposed.
\end{abstract} radish, and tomato causing leaf spots and dark sunken lesions on the middle vein, petiole, and stem. Based on the differential reactions of

Leaf spot diseases caused by Xanthomonas spp. have been reported to cause severe damage in a number of crops belonging to the family Brassicaceae in different countries, including the United States (31), Japan (22), and possibly India and Turkey (3). These diseases have usually been attributed to either X. campestris pv. armoraciae (McCulloch) Dye or X. campestris pv. raphani (White) Dye. X. campestris pv. armoraciae (Bacterium campestre var. armoraciae) was first described by McCulloch (14) as being the causal agent of a nonvascular leaf spot disease of horseradish (Armoracia rusticana): this organism was reported to be only weakly pathogenic on cabbage (Brassica oleracea var. capitata), cauliflower (B. oleracea var. botrytis) (causing spots only on leaves, but no lesions on stems and petioles), stock (Matthiola incana), and lima beans (Phaseolus sp.), and was not pathogenic on kale (B. oleracea var. acephala), mustard (Brassica sp.), radish (Raphanus sativus), candytuft (Iberis sp.), wild cress (Cardamine sp.), Nasturtium, squash (Cucurbita sp.), poppy (Papaver sp.), cotton (Gossypium hirsutum), navy bean (P. vulgaris), and cowpea (Vigna unguiculata) (14). X. campestris pv. raphani (Bacterium vesicatorium var. raphani) was first described by White (28) as the cause of a bacterial spot disease of radish and turnip (B. rapa): this organism was reported to be pathogenic on cabbage, cauliflower, kale, Brussels sprouts (B. oleracea var.

Corresponding author: J. G. Vicente; E-mail address: joana.vicente@warwick.ac.uk

* The $\boldsymbol{e}$-Xtra logo stands for "electronic extra" and indicates that the online version contains supplemental material not included in the print edition. Figures 1 to 5 appear in color online.

DOI: 10.1094/PHYTO-96-0735

(C) 2006 The American Phytopathological Society
Additional keywords: black rot, disease resistance, pathogen variants, races.

gemmifera), mustard, tomato (Lycopersicon esculentum), pepper (Capsicum annuum), and tobacco (Nicotiana tabacum), and was not pathogenic on horseradish, garden cress (Lepidium sativum), Nasturtium, shepherd's purse (Capsella bursa-pastoris), bean (P. vulgaris), soybean (Glycine max), and garden huckleberry (Physalis sp.). All cultivars of radish, mustard and B. oleracea that were tested by White (28) were susceptible to this pathogen.

Serological, genetic and pathogenicity studies by Black and Machmud (2) and Alvarez et al. (1) did not support the separation of $X$. campestris pv. armoraciae from pv. raphani; these authors considered the names synonymous (with the designation armoraciae having priority over raphani). In contrast, White (28) and Tamura et al. (22) found differences between the two pathovars with $X$. campestris pv. raphani having a much larger host range that included radish and tomato, but not horseradish. Sahin and Miller (21) attributed a leaf spot disease of radish to a new pathotype of X. campestris pv. armoraciae; these isolates caused spots on several hosts including cabbage, kale, radish, and horseradish, but not on tomato and pepper.

According to the reclassification of the genus Xanthomonas based on DNA-DNA hybridization (24), the species X. campestris includes four other pathovars that can cause disease in cruciferous plants (pvs. campestris, aberrans, barbareae, and incanae). $X$. campestris pv. campestris (Pammel) Dowson causes black rot of brassicas, possibly the most important disease of crucifers worldwide (29). This pathovar and X. campestris pv. aberrans (Knösel) Dye have also been reported to cause leaf spots in brassicas $(3,31)$, but the symptoms generally progress to include typical V-shape lesions and darkened veins caused by the vascular movement of the pathogen. For this reason, an isolate previously identified as $X$. campestris pv. aberrans has been included in 
$X$. campestris pv. campestris (27). Recently, Vicente et al. (27) reported that isolates from ornamental crucifers, stock (M. incanae), wallflower (Cheiranthus cheiri), and candytuft (previously included in $X$. campestris pv. incanae (Kendrick \& Baker) Dye, $X$. campestris pv. campestris and X. campestris pv. armoraciae, respectively), caused vascular diseases and showed pathovar-like specificity to their hosts of origin. In addition to distinctions based on host range (pathovars), several Xanthomonas species or pathovars can be further differentiated into races based on their interactions with differential cultivars. Thus, six races were proposed for $X$. campestris pv. campestris based on the response of certain Brassica species and cultivars $(7,27)$. $X$. campestris pv. vesicatoria has been divided into two species, $X$. axonopodis pv. vesicatoria and $X$. vesicatoria (24), with different races (6).

Repetitive DNA-polymerase chain reaction (PCR)-based genomic fingerprinting (rep-PCR) with REP (targeting the repetitive extragenic palindromic sequence), ERIC (targeting the enterobacterial repetitive intergenic consensus), and BOX (targeting the DNA sequences of the BOXA subunit of the BOX element of Streptococcus pneumonia) primers is a rapid and useful technique to assess the bacterial diversity at the species, pathovar, and isolate level $(11)$. Rademaker et al. $(16,18)$ have shown that repPCR can separate a number of Xanthomonas species and pathovars and that the results are highly correlated with results obtained in DNA-DNA homology studies and therefore seem to reflect their phylogenetic relationships.

In this paper, we present the results of work done to clarify the taxonomy of Xanthomonas isolates that cause leaf spots on bras- sicas and other hosts. We also present information on the occurrence of pathogenic variants (races), describe a differential series for the determination of races of $X$. campestris leaf spot isolates, and propose a gene-for-gene model to explain the interaction of races and differential cultivars. In addition, the genetic variability of X. campestris leaf spot isolates together with representatives of $X$. campestris pv. campestris and closely related Xanthomonas pathovars was studied using rep-PCR.

\section{MATERIALS AND METHODS}

Bacterial isolates. The isolates used in this study are listed in Table 1. Isolates originally identified as either X. campestris pvs. armoraciae or raphani were mainly obtained from researchers and seed companies from different countries. In addition, two isolates were obtained from commercial seed lots, as part of studies done at Warwick HRI, Wellesbourne (20). Isolates were initially considered to be $X$. campestris on the basis of colony characteristics on yeast dextrose chalk (YDC) agar (30) and/or King's medium B (KB) (8) and agglutination tests (12). The isolate HRI 6489 was similar to other $X$. campestris isolates except for lack of yellow pigmentation (15). For comparative purpose, representative isolates of the six races of $X$. campestris pv. campestris and of other closely related $X$. campestris pathovars from cruciferous hosts from the Warwick HRI culture collection (27) and representative $X$. vesicatoria and $X$. axonopodis pv. vesicatoria isolates (10) were also included (Table 1).

For long-term storage, bacterial growth was suspended in a liquid medium containing nutrient broth (8 g/liter) (Difco Labora-

TABLE 1. Source and origin of isolates used in this study

\begin{tabular}{|c|c|c|c|c|c|}
\hline HRI isolate number (previous designation) & Source $(\text { reference })^{\mathrm{a}}$ & Host & $\begin{array}{l}\text { Infected } \\
\text { material }\end{array}$ & Geographical origin & $\begin{array}{c}\text { Year of } \\
\text { isolation }\end{array}$ \\
\hline \multicolumn{6}{|l|}{$\begin{array}{l}\text { Xanthomonas campestris pv. raphani isolates } \\
\text { (pathogenic on Savoy cabbage cv. Wirosa } \mathrm{F}_{1} \\
\text { and tomato cv. Moneymaker) }\end{array}$} \\
\hline \multicolumn{6}{|l|}{ RACE 1} \\
\hline 6489 (B-122) & M. Asma, ex. R. Morrison (15) & & & Arizona, U.S. & 1984 \\
\hline $6490(\mathrm{P} 5034)^{\mathrm{b}}$ & M. Asma & $\begin{array}{l}\text { Brassica oleracea } \\
\text { var. botrytis }\end{array}$ & Seed & France & 1995 \\
\hline 6496 (A4641) & M. Asma, ex. A. Alvarez & & & & \\
\hline 7974 & Warwick HRI (20) & B. oleracea var. capitata & Seed & Southern Hemisphere & 2000 \\
\hline 7979 & Warwick HRI (20) & B. oleracea var. capitata & Seed & Southern Hemisphere & 2000 \\
\hline 8079 (071) & H. Bouzar & & & & \\
\hline $8297(62-9)$ & D. Cuppels, ex. R. Stall (10) & Raphanus sativus & & & \\
\hline $8298(0-71)$ & D. Cuppels, ex. W. Wiebe (10) & Raphanus sativus & & Minnesota, U.S. & \\
\hline \multicolumn{6}{|l|}{ RACE 2} \\
\hline $6492(\mathrm{P} 5056)$ & M. Asma & B. oleracea var. capitata & Seed & France & 1995 \\
\hline 6494 (P5082) & M. Asma & B. oleracea var. capitata & Seed & France & 1995 \\
\hline 6498 (P5155) & M. Asma & & Plant & & 1998 \\
\hline 6499 (P5159) & M. Asma & & Plant & & 1998 \\
\hline 6519 (TMR74) b,c & K. Tamura (22) & Raphanus sativus & Leaves & Shizuoka, Japan & 1985 \\
\hline 8299 (DC 91-2) & D. Cuppels (10) & Lycopersicon esculentum & Plant & Ontario, Canada & \\
\hline 8303 (BR-11) & J. Damicone (31) & B. rapa var. utilis & Leaves & Oklahoma, U.S. & 1994 \\
\hline 8304 (BR-16) & J. Damicone (31) & B. rapa var. utilis & Leaves & Oklahoma, U.S. & 1995 \\
\hline 8307 (XLS 6) & J. Damicone, ex. L. L. Black (31) & B. oleracea var. capitata & & North Carolina, U.S. & \\
\hline $8308(756)$ & J. Damicone, ex. D. Gabriel (31) & B. oleracea var. capitata & Seed & E. Asia & \\
\hline $8309(3145)$ & J. Damicone, ex. Stall (31) & & & Florida, U.S. & \\
\hline
\end{tabular}

a Warwick HRI, Wellesbourne, U.K.; NCPPB, National Collection of Plant Pathogenic Bacteria, Sand Hutton, U.K.

${ }^{\mathrm{b}}$ Proposed race-type strains of $X$. campestris pv. raphani.

${ }^{c}$ Proposed neopathotype strain of $X$. campestris pv. raphani.

${ }^{\mathrm{d}}$ Race-type strains of $X$. campestris pv. campestris.

e NCPPB type strains of Xanthomonas species/pathovars. 
tories, Detroit) and glycerol (150 ml/liter) and maintained on glass beads at $-76^{\circ} \mathrm{C}(4)$.

Pathogenicity to $B$. oleracea. The cultivars and accessions used in this study are listed in Table 2. Plants of Savoy cabbage cv. Wirosa $F_{1}$ and cauliflower cv. Miracle $F_{1}$ were used for initial pathogenicity tests done by spray inoculation. Two plants of each cultivar were tested per isolate. Several re-isolations were performed to confirm the presence of bacteria in association with disease symptoms (leaf spots, vein and stem sunken lesions).

Host range. Twenty-one accessions/cultivars including hosts previously used in host range studies of $X$. campestris pathovars and races (27) (Table 2) were used to determine the host range of 12 isolates that caused leaf spots in the initial pathogenicity tests (HRI 6489, 6490, 6492, 6496, 6497, 6499, 6518, 7979, 8079, 8299,8304 , and 8305), two NCPPB isolates received as $X$. campestris pv. armoraciae (HRI 6375 and 6376), two X. campestris pv. campestris isolates (HRI 1279A and 3880), and an X. vesicatoria isolate (HRI 8300) by both spray inoculation and pin inoculation. Two to three plants of each accession were tested with each method except for horseradish (A. rusticana), cucumber (Cucumis sativus), pumpkin (Cucurbita maxima), and tobacco ( N. tabacum) where only one plant was tested with each method.
A subset of 10 plant accessions (Table 2) including a selection of six Brassica cultivars, two radish cultivars, one wallflower cultivar, and one tomato cultivar was used to characterize a further 13 isolates that caused leaf spots, together with two isolates of $X$. campestris pv. campestris (HRI 3811 and 3883), two isolates of $X$. vesicatoria (HRI 5235 and 8302), and one isolate of $X$. axonopodis pv. vesicatoria (HRI 8301) by spray inoculation. One plant of each inbred line, $\mathrm{F}_{1}$ hybrid, and self-fertilizing accession and two plants of each open pollinated accession were tested with each isolate.

Inoculations. Plants were raised from seed sown in $7 \mathrm{~cm}$ square plastic pots filled with Levington M2 compost (Scotts) and grown in a glasshouse with a minimum temperature of $20 / 15^{\circ} \mathrm{C}$ (day/night), venting at $22 / 17^{\circ} \mathrm{C}$ (day/night), and supplementary lighting from October to March to give $16 \mathrm{~h}$ days. Plants were inoculated approximately 4 weeks after sowing. Isolates were grown on $\mathrm{KB}$ at $30^{\circ} \mathrm{C}$ for $48 \mathrm{~h}$ before inoculation.

For spray inoculations, inoculum was prepared by suspending the bacteria in sterile tap water $\left(10^{8}\right.$ to $\left.10^{9} \mathrm{CFU} / \mathrm{ml}\right)$. Bacterial suspensions were sprayed onto the plants including the upper and the under surface of leaves with a DeVilbiss Atomizer 15 (DeVilbiss Health Care, Inc., Sommerset, PA) connected to an electrical pump. Plants were sprayed gently, until wet, by holding

TABLE 1. (Continued from preceding page)

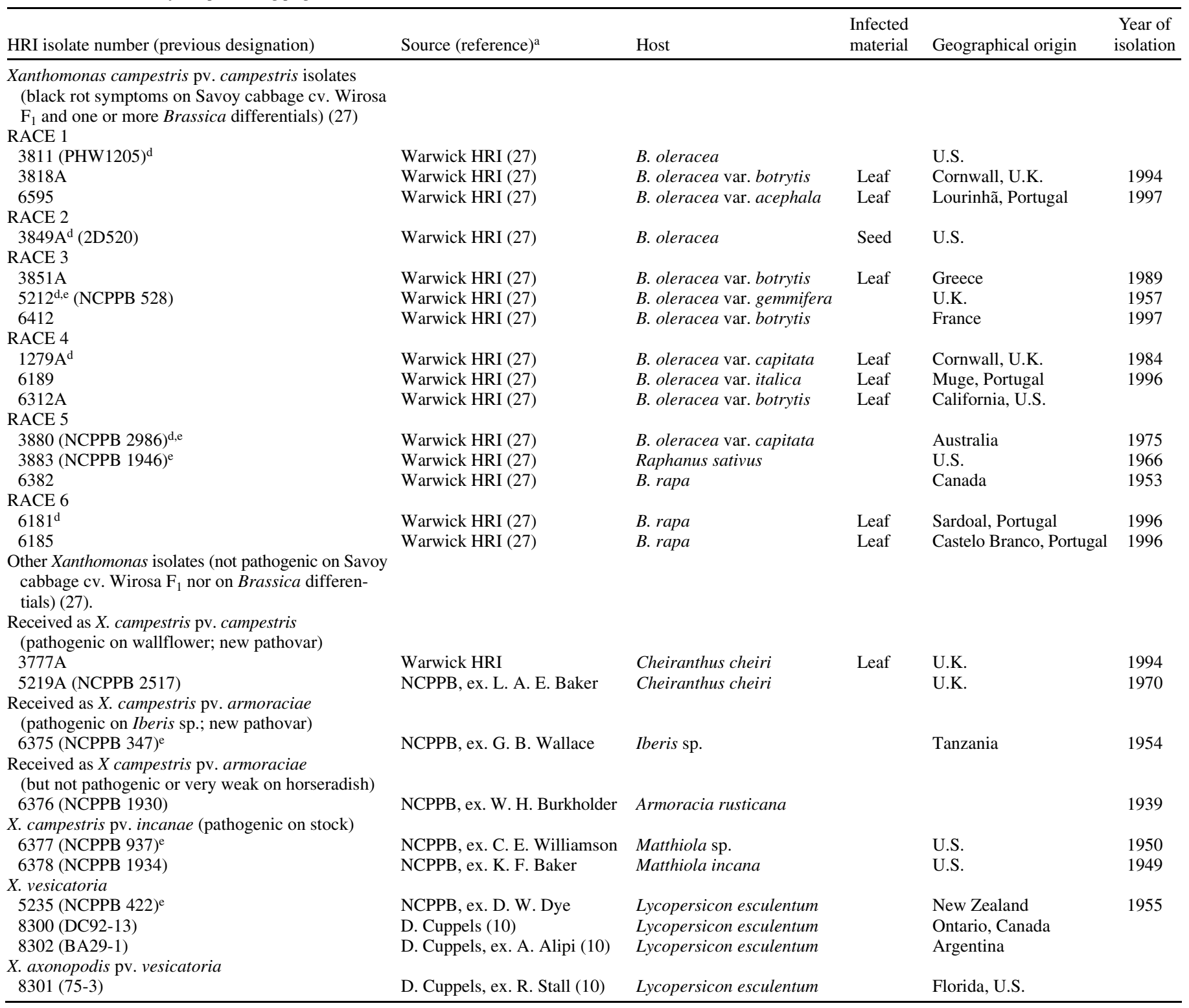


the spray nozzle at a distance of 10 to $15 \mathrm{~cm}$. In addition, the spray nozzle was held close to the under surface of a leaf in each plant to force the bacterial suspension into the tissues in two small areas $(0.5 \mathrm{~cm}$ diameter). After inoculation, plants were kept at $20 \pm 1{ }^{\circ} \mathrm{C}$, under conditions of high humidity, in cabinets with controlled mist spray equipment. Plants were kept in the mist cabinets for $48 \mathrm{~h}$ in the preliminary test and for $24 \mathrm{~h}$ in all subsequent experiments before returning to normal glasshouse conditions.

For pin inoculations, the middle vein and petiole of the three youngest expanded leaves were inoculated by stabbing in three to five places with a sterile entomological mounting pin charged with bacterial growth from a plate. Symptoms were recorded 7 and 14 days after inoculation.

rep-PCR. Isolates were grown on $\mathrm{KB}$ at $30^{\circ} \mathrm{C}$ for $24 \mathrm{~h}$ and the growth was used to prepare $3 \mathrm{ml}$ of suspension containing $10^{8}$ to $10^{9}$ cells $/ \mathrm{ml}$. Cells from $1.5 \mathrm{ml}$ of these suspensions were harvested by centrifugation for $10 \mathrm{~min}$ at $13,000 \mathrm{rpm}(12,600 \times g)$ in a microcentrifuge (MSE Microcentaur, Loughborough, UK). DNA was extracted using the Qiagen DNeasy tissue extraction kit (Qiagen Ltd., West Sussex, UK) according to the manufacturer's protocol for extraction of DNA from bacteria and animal tissues. DNA concentration was estimated after running samples on an agarose gel alongside known amounts of Lambda DNA. Primer sequences corresponding to REP1R (5'-IIIICGICGICATCIGGC3'), REP2I (5'-ICGICTTATCIGGCCTAC-3'), ERIC1R (5'-ATGTAAGCTCCTGGGGATTCAC-3'), ERIC2 (5'-AAGTAAGTGACTGGGGTGAGCG-3'), and BOXA1R (5'-CTACGGCAAGGCGACGCTGACG-3') $(25,26)$ were synthesized by Operon Technologies, Inc. (Alameda, CA).

rep-PCR was carried out as described in Rademaker et al. (17) with minor modifications. PCR analyses were carried out in a total volume of $20 \mu \mathrm{l}$ containing $1 \times$ Gitschier buffer (9), $3.5 \mathrm{mM}$ $\mathrm{MgCl}_{2}$ for REP and $1.75 \mathrm{mM}$ for ERIC and BOX, $2 \mu \mathrm{l}$ of dimethylsulfoxide (DMSO) (FULKA, Dorset, UK), $3.2 \mu \mathrm{g}$ of bovine serum albumin (BSA) (Roche, Mannheim, Germany), $40 \mathrm{pmol}$ of each primer (two primers for REP and ERIC and one primer for BOX), $1.25 \mathrm{mM}$ of each of four deoxynucleoside triphosphates, 1.6 unit of Taq DNA polymerase (Invitrogen), and approximately $40 \mathrm{ng}$ of template genomic DNA. PCR amplification was performed in a Genius (Techne (Cambridge) Limited, Duxford, Cambridge, UK) thermocycler with the following program: one cycle at $95^{\circ} \mathrm{C}$ for $2 \mathrm{~min} ; 30$ cycles of denaturation at $94^{\circ} \mathrm{C}$ for $3 \mathrm{~s}$ and $92^{\circ} \mathrm{C}$ for $30 \mathrm{~s}$, annealing at 40,52 , or $53^{\circ} \mathrm{C}$ for 1 min with REP, ERIC, and BOX primers, respectively, extension at $65^{\circ} \mathrm{C}$ for $8 \mathrm{~min}$; single extension at $65^{\circ} \mathrm{C}$ for $8 \mathrm{~min}$; and finally held at $4^{\circ} \mathrm{C}$. Three PCR reactions were carried out with each set of primers and two control isolates (HRI 3811 and HRI 6519) were included in every run.

Aliquots of amplified REP- (7.5 $\mu \mathrm{l})$, ERIC- $(2.5 \mu \mathrm{l})$, and BOXPCR $(2.5 \mu \mathrm{l})$ products of each strain (and of blank controls) were analyzed by electrophoresis in a $1.2 \%$ agarose gel with ethidium bromide at $0.5 \mu \mathrm{g} / \mathrm{ml}$ in $0.5 \times$ Tris-borate-EDTA buffer for $8 \mathrm{~h}$ at $60 \mathrm{~V}$ (approximately $1.8 \mathrm{~V} / \mathrm{cm}$ ) and photographed under UV light. Three 22-lane gels were run for each set of primers. A molecular mass marker (1-kb-plus DNA ladder, Invitrogen) was loaded into both edge and middle lanes of each gel.

The rep-PCR fingerprint profiles were used to measure the genetic similarity between strains. A digital image of each gel was analyzed using the Fingerprinting II software (Bio-Rad Laboratories, Hercules, CA). The disk background subtraction method was applied. Gels were normalized using the standards loaded into the edge and middle lanes of each gel. Cluster analysis of the pairwise similarity values was performed using the Dice similarity coefficient and unweighted pair-group method with arithmetic means (UPGMA) clustering technique. The results of REP-, ERIC-, and BOX-PCR genomic fingerprinting were combined using the Fingerprinting II software.

\section{RESULTS}

Pathogenicity of isolates on $\boldsymbol{B}$. oleracea. In initial spray inoculations of Savoy cabbage cv. Wirosa $F_{1}$ and cauliflower cv. Miracle $F_{1}, 25$ isolates from brassicas, radish, and tomato, re-

TABLE 2. Origin of 21 plant accessions used for characterization of the host range and their reaction to the Xanthomonas campestris pv. raphani isolates ${ }^{\mathrm{a}}$ tested in this study

\begin{tabular}{|c|c|c|c|c|}
\hline Species/variety & Cultivar or accession & Type & Origin & Reaction \\
\hline \multicolumn{5}{|l|}{ Brassica spp. } \\
\hline Ethiopian mustard (B. carinata) & Selection of PI $199947^{b}$ & Inbred line & Warwick HRI; ex. Ethiopia & Very susceptible \\
\hline Mustard (B. juncea) & Florida Broad Leaf Mustard ${ }^{b}$ & Open-pollinated & Otis S. Twilley Seed Co., U.S. & Resistant to race 1 \\
\hline Turnip (B. rapa var. rapifera) & Just Right Hybrid Turnip ${ }^{b}$ & Hybrid & Otis S. Twilley Seed Co., U.S. & Resistant to race 1 \\
\hline Turnip (B. rapa var. rapifera) & Seven Top Turnip & Open-pollinated & Otis S. Twilley Seed Co., U.S. & Variable; resistant to race 1 \\
\hline Cauliflower (B. oleracea var. botrytis) & Miracle $\mathrm{F}_{1} \mathrm{~b}$ & Hybrid & Bejo Zaden NV, Netherlands & Resistant to race 2 \\
\hline Radish (Mooli) (R. sativus) & Mino Earlyb & Open-pollinated & Suttons Seeds, U.K. & Resistant to race 2 \\
\hline Horseradish (Armoracia rusticana) & - & Vegetative propagation & Garden centre, U.K. & Weakly susceptible \\
\hline \multicolumn{5}{|l|}{ Ornamental crucifers } \\
\hline Hyacinth flowered candytuft (Iberis sp.) & White Empress & Open-pollinated & Unwins Seeds, U.K. & Variable \\
\hline Perennial candytuft (Iberis sempervivens) & Snowflake & Open-pollinated & Unwins Seeds, U.K. & Variable \\
\hline Stock (Matthiola incana) & Brompton Mixed colours & Open-pollinated & Suttons Seeds, U.K. & Resistant to all races \\
\hline Stock (M. incana) & Heaven Scent & Open-pollinated & Suttons Seeds, U.K. & Resistant to all races \\
\hline Pumpkin (Cucurbita maxima) & $\mathrm{F}_{1}$ Becky & Hybrid & Suttons Seeds, U.K. & Susceptible \\
\hline Cucumber (Cucumis sativus) & Telegraph Improved & Open-pollinated & Suttons Seeds, U.K. & Susceptible \\
\hline Tobacco (Nicotiana tabacum) & White Burley & Self-pollinated & Warwick HRI, U.K. & Susceptible \\
\hline Pepper (Capsicum аппиит) & Worldbeater & Self- or open-pollinated & Suttons Seeds, U.K. & Resistant to race 2 \\
\hline
\end{tabular}

${ }^{a}$ Twelve X. campestris pv. raphani isolates (HRI 6489, 6490, 6492, 6496, 6497, 6499, 6518, 7979, 8079, 8299, 8304, and 8305) were inoculated in all accessions. Other isolates were inoculated in a subset of 10 accessions.

b Subset of 10 accessions used to study the host range of $X$. campestris pv. raphani isolates. 
ceived from different researchers/seed companies as $X$. campestris pv. armoraciae or $X$. campestris pv. raphani or isolated at Warwick HRI, gave symptoms generally typical of the leaf spot disease described by White (28) as caused by X. campestris pv. raphani: circular dark spots were visible less than 1 week after inoculation; the spots later became light brown or gray, sometimes surrounded by a water-soaked halo (Fig. 1, left). In severely affected leaves, the spots coalesced and became irregular, but were not limited by the veins. Most isolates also produced black, sunken, elongated lesions on the middle vein, petiole, and/or stem in one or both cultivars (Fig. 1, left). In some cases, the petioles became bent and young leaves were distorted. Twenty-one of the isolates produced leaf spots on both cultivars, but four isolates (HRI 6497, 6518, 6520, and 8305) produced leaf spots only on cv. Wirosa $F_{1}$. The presence of $X$. campestris was confirmed after reisolation from lesions; these isolates produced similar symptoms when re-inoculated into Wirosa $F_{1}$ and Miracle $F_{1}$ (data not shown).

Representative isolates of the six $X$. campestris pv. campestris races (race 1, HRI 3811; race 2, HRI 3849A; race 3, HRI 5212; race 4, HRI 1279A; race 5, HRI 3880 and 3883; and race 6, HRI 6181) were also spray-inoculated onto cvs. Wirosa $F_{1}$ and Miracle $\mathrm{F}_{1}$. Some of these isolates initially produced small water-soaked dark spots and chlorosis, but the symptoms later progressed toward typical V-shape yellow lesions (Fig. 1, right). All X. campestris pv. campestris isolates produced black rot symptoms on cv. Wirosa $F_{1}$, except the race 2 isolate. The isolates of races 3, 5, and 6 did not produce any black rot symptoms on cv. Miracle $F_{1}$. Two isolates received from the National Collection of Plant Pathogenic Bacteria (NCPPB), York, UK, as X. campestris pv. armoraciae (HRI 6375 and 6376) and isolates of $X$. vesicatoria
(HRI 5275, 8300, and 8302) and $X$. axonopodis pv. vesicatoria (HRI 8301) were not pathogenic when spray-inoculated onto cvs. Wirosa $F_{1}$ and Miracle $F_{1}$.

Host range. In spray inoculations with the leaf spot isolates, hosts that were considered susceptible developed leaf spots and frequently showed dark sunken lesions on the middle vein, petiole, and/or stem (Fig. 2, left). In pin inoculations, these same hosts developed dark sunken lesions around the inoculation points (Fig. 2, center). The results are summarized in Table 2. Plants of $B$. oleracea $\mathrm{cv}$. Wirosa $\mathrm{F}_{1}$, a selection of $B$. carinata accession PI 199947, radish cv. French Breakfast 3 (Fig. 3), and tomato cv. Moneymaker (Fig. 4, left) were very susceptible to the 12 leaf spot isolates tested. Large numbers of spots and sunken lesions were observed in the leaves, petioles, and stems of spray-inoculated plants of these hosts. The B. napus cv. Cobra line 14R, B. rapa cv. Just Right Hybrid Turnip, B. juncea cv. Florida Broad Leaf Mustard, and the two wallflower cultivars were resistant to five leaf spot isolates (HRI 6489, 6490, 6496, 7979, and 8079), while $B$. oleracea $\mathrm{cv}$. Miracle $\mathrm{F}_{1}$ and radish cv. Mino Early were resistant to three leaf spot isolates (HRI 6497, 6518, and 8305) (Fig. 2, right). The B. rapa cv. Seven Top Turnip and the candytuft cultivars were mixtures and included both resistant and susceptible individuals when inoculated with the same isolate (Table 2 ). The two stock cultivars were resistant to all 12 leaf spot isolates tested. The pepper cv. Worldbeater was resistant to three isolates (HRI 6497, 6518, and 8305) and was susceptible to the other isolates (Fig. 4, center). The pumpkin cv. Becky $\mathrm{F}_{1}$, cucumber cv. Early Telegraph, and tobacco cv. White Burley (Fig. 4, right) were susceptible to the 12 leaf spot isolates, although generally these isolates did not seem to be very aggressive on these hosts. The horseradish plants that were sprayed showed several

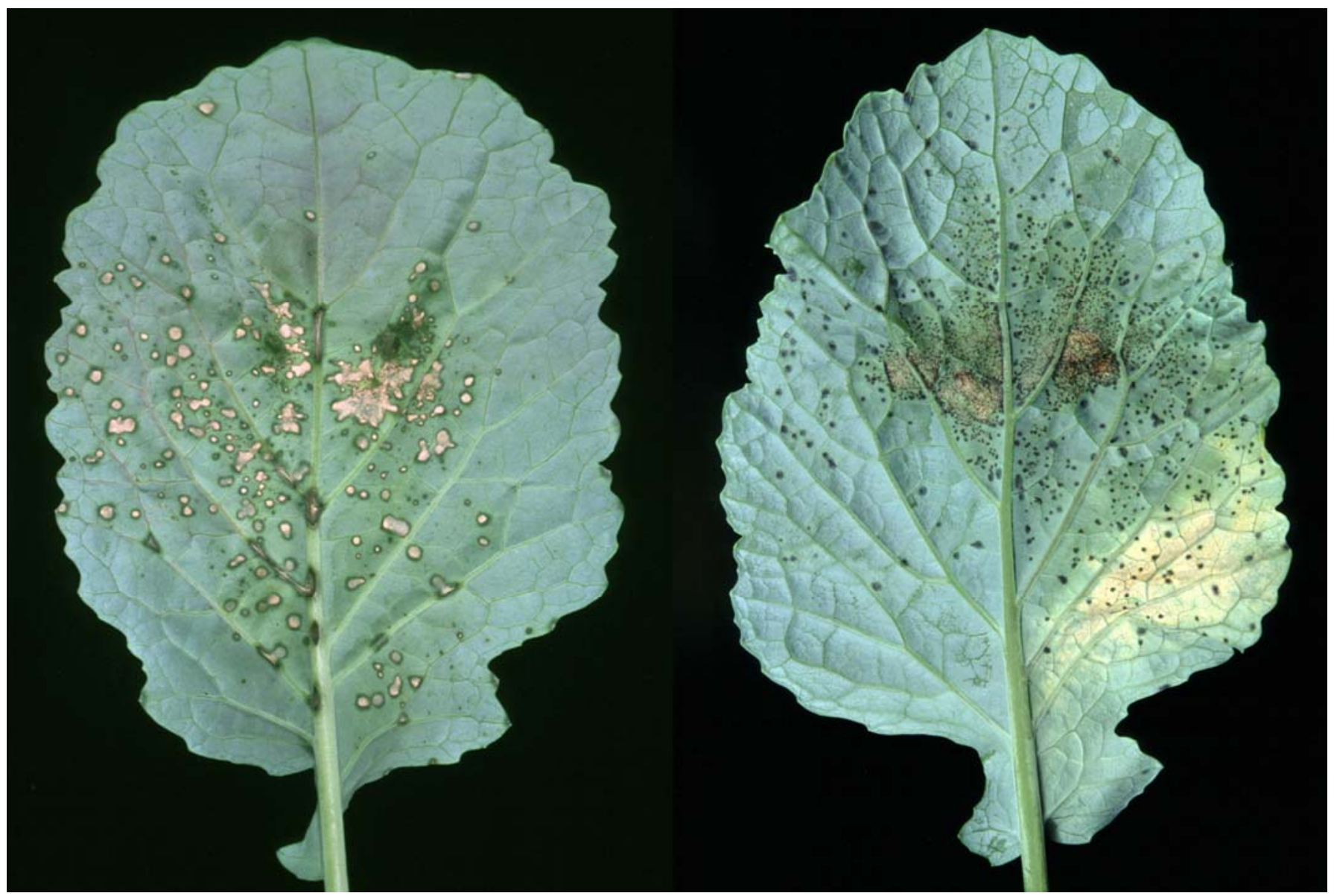

Fig. 1. Savoy cabbage cv. Wirosa $\mathrm{F}_{1}$ leaves (abaxial side) spray-inoculated with Xanthomonas campestris pv. raphani isolate 8305 (left, 2 weeks after inoculation) and $X$. campestris pv. campestris isolate 3883 (right, 3 weeks after inoculation). 
spots and the pin-inoculated plants had small lesions around the inoculation points, but the symptoms were generally weak.

The two X. campestris pv. campestris isolates (HRI 1279A and 3880) caused dark spots and chlorosis that progressed to typical black rot symptoms on $B$. oleracea $\mathrm{cv}$. Wirosa $\mathrm{F}_{1}$ and on radish cv. French Breakfast 3. The race 4 isolate (HRI 1279A) was not pathogenic on B. rapa cv. Just Right Turnip, B. napus line 14R of Cobra, $B$. juncea cv. Florida Broad Leaf Mustard, and $B$. carinata selection of PI 199947. The race 5 isolate (HRI 3880) was not pathogenic on B. oleracea cv. Miracle and radish cv. Mino Early and was just very weakly pathogenic on $B$. juncea cv. Florida Broad Leaf Mustard. B. rapa cv. Seven Top Turnip gave variable reactions with these two isolates. The two $X$. campestris pv. campestris isolates (HRI 1279A and 3880) were not pathogenic on other plants tested.

The $X$. vesicatoria isolate (HRI 8300) was only pathogenic on tomato and pepper. The symptoms on these hosts were distinct from the symptoms caused by the $X$. campestris leaf spot isolates: the spots caused by $X$. vesicatoria were generally smaller, darker and more irregular than spots caused by the $X$. campestris leaf spot isolates.

Host range on a subset of $\mathbf{1 0}$ hosts. The 13 leaf spot isolates tested were pathogenic on B. oleracea cv. Wirosa $\mathrm{F}_{1}, B$. carinata selection of PI 199947, radish cv. French Breakfast 3, and tomato cv. Moneymaker. Five isolates (HRI 6491, 6493, 7974, 8297, and 8298) were not pathogenic on B. napus line 14R of Cobra, B. rapa cv. Just Right Hybrid Turnip, and B. juncea cv. Florida Broad Leaf Mustard; some of these isolates produced a small number of spots in wallflower. One isolate (HRI 6520) was not pathogenic on $B$. oleracea $\mathrm{cv}$. Miracle $\mathrm{F}_{1}$ and radish cv. Mino Early. The remaining seven leaf spot isolates were pathogenic on all of these hosts.

The $X$. campestris pv. campestris race 1 isolate (HRI 3811) caused black rot symptoms in three Brassica cultivars (Wirosa $F_{1}$, Miracle $F_{1}$, and Just Right Turnip) and both cultivars of radish; the race 5 isolate (HRI 3883) caused black rot symptoms on three Brassica cultivars (Wirosa $F_{1}$, selection of PI 199947, and Just Right Hybrid Turnip) and radish cv. French Breakfast, and was weakly pathogenic on B. juncea cv. Florida Broad Leaf Mustard and radish cv. Mino Early.

The $X$. vesicatoria (HRI 5235 and 8302) and $X$. axonopodis pv. vesicatoria (HRI 8301) isolates produced small dark irregular spots on tomato and no symptoms on other hosts.

Occurrence of races. The differential reactions of Brassica, radish, and wallflower cultivars were used to separate the $X$. campestris leaf spot isolates into three races (Fig. 5). Race 1 isolates were not pathogenic on B. napus line 14R of Cobra, B. rapa cv. Just Right Hybrid Turnip, and $B$. juncea cv. Florida Broad Leaf Mustard; these isolates were also not pathogenic or very weakly pathogenic on wallflower cv. Cloth of Gold. Race 2 isolates were not pathogenic on B. oleracea $\mathrm{cv}$. Miracle $\mathrm{F}_{1}$ and radish cv. Mino Early. Race 3 isolates were pathogenic on all these cultivars. Ten $X$. campestris leaf spot isolates were included in race 1 , four in race 2 , and 11 in race 3 (Tables 1 and 3 ).

rep-PCR. The patterns of the fingerprints of 50 Xanthomonas isolates were generated by REP-, ERIC-, and BOX-PCR. These patterns were complex with a number of polymorphic bands. Twenty-four bands were identified in REP, 32 in ERIC, and 38 in BOX-PCR (ranging from approximately $200 \mathrm{bp}$ up to $4.0 \mathrm{~kb}$ ). The cophenetic correlation (that measures the correlation between distance values calculated during dendrogram building and the observed distance) was $0.79,0.68$, and 0.74 for REP, ERIC, and BOX dendrograms, respectively. The data obtained with the three sets of primers were combined and used to generate a dendrogram (Fig. 6). The cophenetic correlation for this "combined" dendrogram was 0.83 , showing that the clustering was more accurate after combining the results. The profiles of the two isolates that were repeated in every PCR and every gel were 91 to $99 \%$ similar (data not shown); therefore, differentiation of isolates that appear more than $90 \%$ similar might be unreliable.

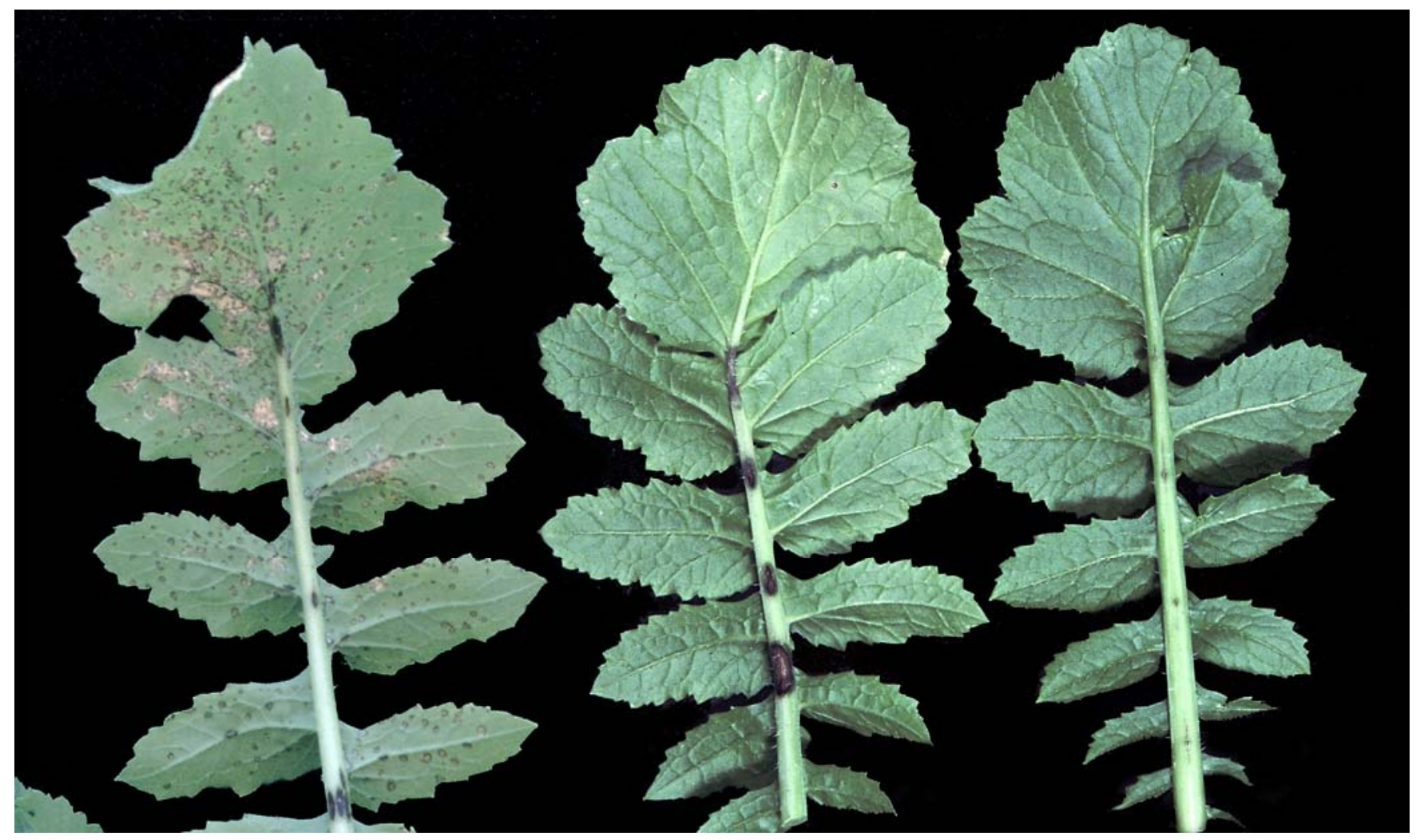

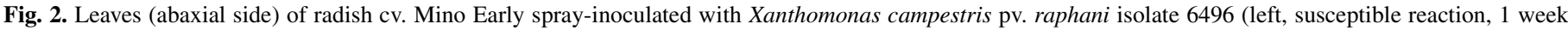

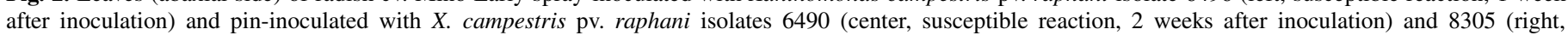
resistant reaction, 3 weeks after inoculation). 
At $60 \%$ similarity, the $X$. vesicatoria and $X$. axonopodis pv. vesicatoria isolates were separated from all the $X$. campestris isolates included in this study; at approximately $68 \%$ similarity, the $X$. axonopodis pv. vesicatoria isolate separated from the three

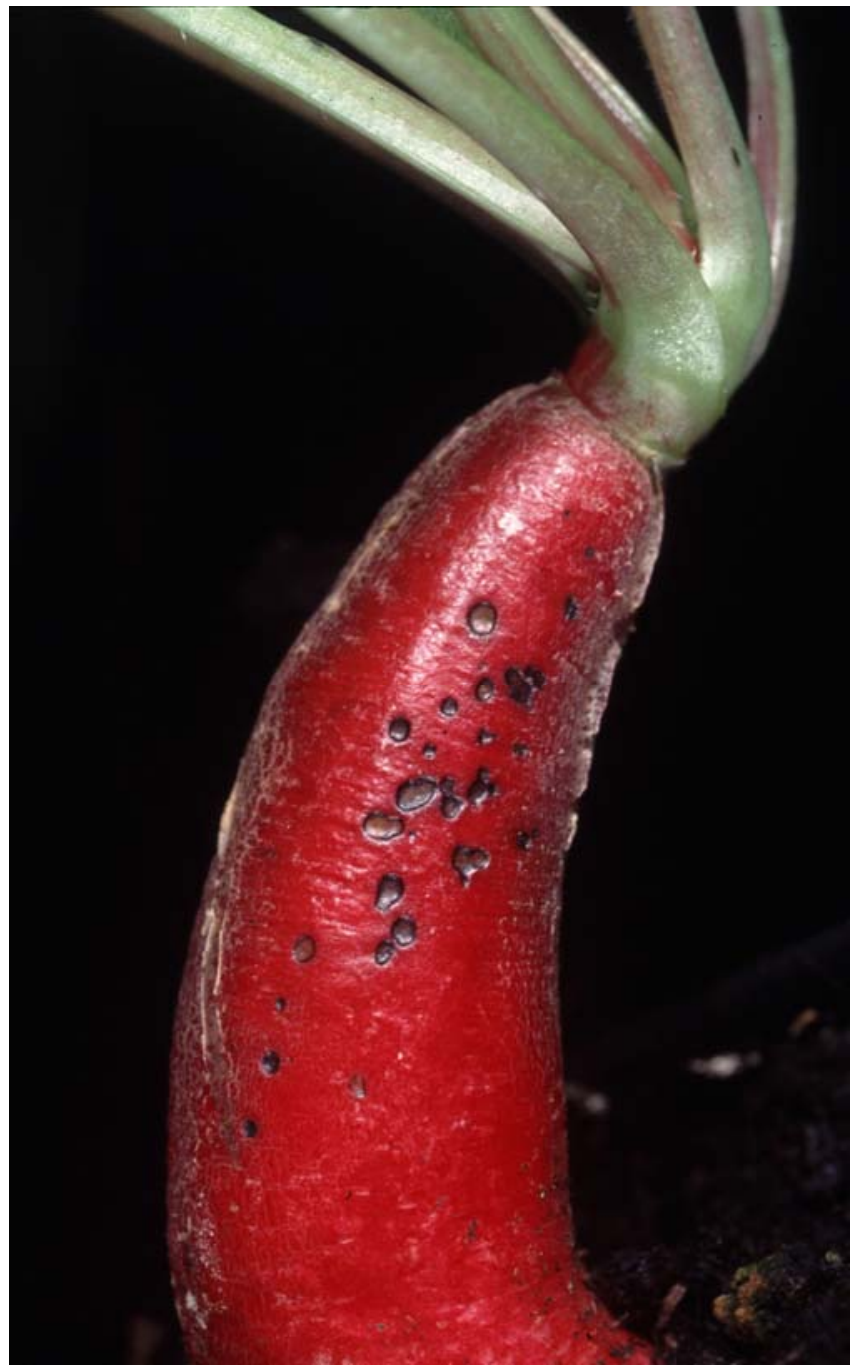

Fig. 3. Radish cv. French Breakfast (swollen hypocotyl) spray-inoculated with Xanthomonas campestris pv. raphani isolate 8298 (2 weeks after inoculation).
$X$. vesicatoria isolates. At $73 \%$ similarity, the isolates obtained from wallflower (HRI 3777A and 5219A) separated from other Xanthomonas isolates from crucifers. At $75 \%$ similarity, two groups of isolates from crucifers were differentiated: one cluster included all leaf spot isolates, an isolate from horseradish (HRI 6376), and the two isolates from stock (HRI 6377 and 6378); the other cluster included all $X$. campestris pv. campestris isolates plus an isolate from candytuft (HRI 6375). Within each race of the leaf spot isolates and each race of $X$. campestris pv. campestris, there were isolates that were very similar or identical, but there were also isolates that were quite distinct.

\section{DISCUSSION}

The nomenclature used in previous papers for isolates of $X$. campestris that cause a nonvascular leaf spot disease on Brassica spp. is confusing, and isolates have been identified as either $X$. campestris pv. armoraciae or $X$. campestris pv. raphani. Such isolates are sometimes obtained during tests on commercial brassica seed (20) and the confusion in their nomenclature presents a problem when reporting results, particularly if the seed is crossing international boundaries (e.g., both $X$. campestris pvs. armoraciae and raphani are officially classified as nonindigenous in the UK). This study aimed to clarify the nomenclature of $X$. campestris leaf spot isolates.

The symptoms observed after spray and pin inoculation of the Xanthomonas leaf spot isolates were similar to the symptoms described by White (28) (Figs. 1, 2, and 3). The isolates were only weakly pathogenic on horseradish, but were very pathogenic in some Brassica spp., radish, and tomato cultivars (Fig. 4). In contrast with the disease described by White (28), the horseradish disease described 1 year earlier by McCulloch (14) had a narrower host range and was not reported to produce dark sunken lesions on stems and petioles. The only isolate studied here that originated from horseradish (HRI 6376) was nonpathogenic and failed to produce leaf spots on either horseradish or the other hosts tested. Although other cultivars of horseradish might be more susceptible to the disease, it is unlikely that we have seen the organism described by McCulloch (14). Because the diseases described by McCulloch (14) and White (28) seem to have different host ranges and possibly produce different symptoms, both their pathovar names should stand and one name should not have priority over the other as previously considered by Black and Machmud (2) and Alvarez et al. (1). Previously, Tamura et al. (22) identified his leaf spot isolates from Japan as $X$. campestris pv.

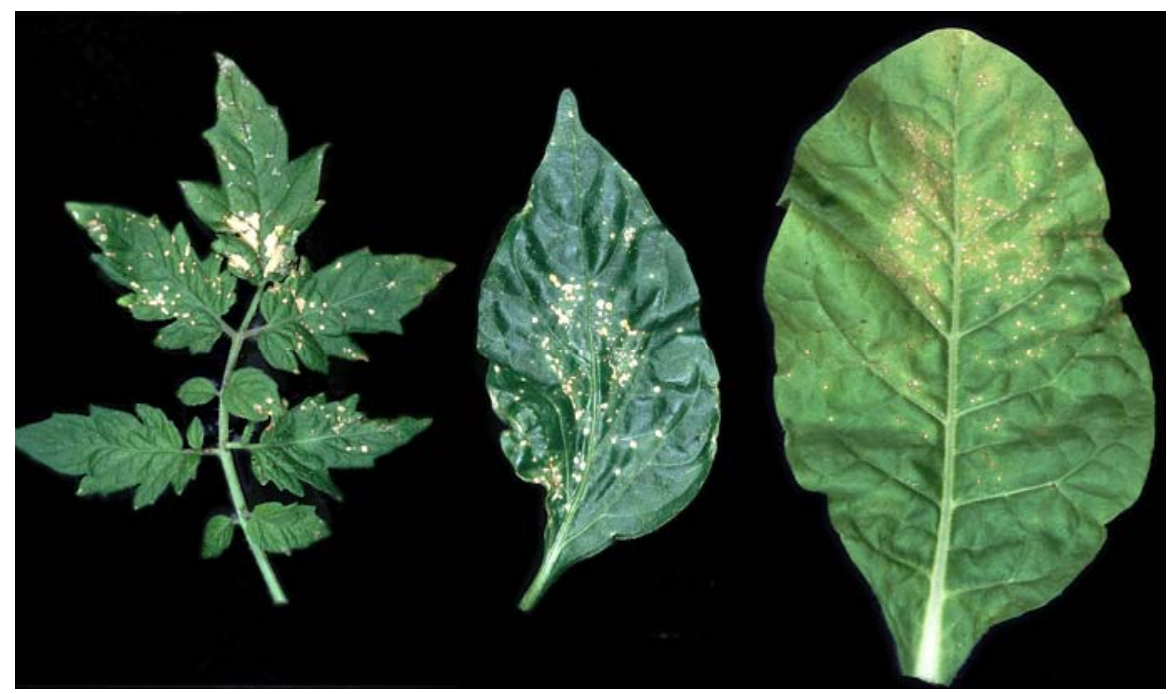

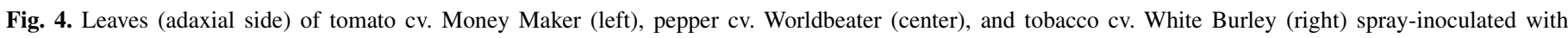
Xanthomonas campestris pv. raphani isolate 6490 (2 weeks after inoculation). 
raphani because they had a large host range that included radish and tomato, but not horseradish. The leaf spot disease of radish described by Sahin and Miller (21) as caused by a different pathotype of $X$. campestris pv. armoraciae also seems to be distinct from the disease studied here as the pathogen attacked horseradish, but not tomato. Therefore, we consider that all the leaf spot isolates that we have studied should be considered as $X$. campestris pv. raphani and not $X$. campestris pv. armoraciae.

Although the $X$. campestris pv. raphani isolates can cause leaf spots when inoculated in pumpkin, cucumber, and tobacco (Fig. $4)$, they were generally not very aggressive on these hosts and

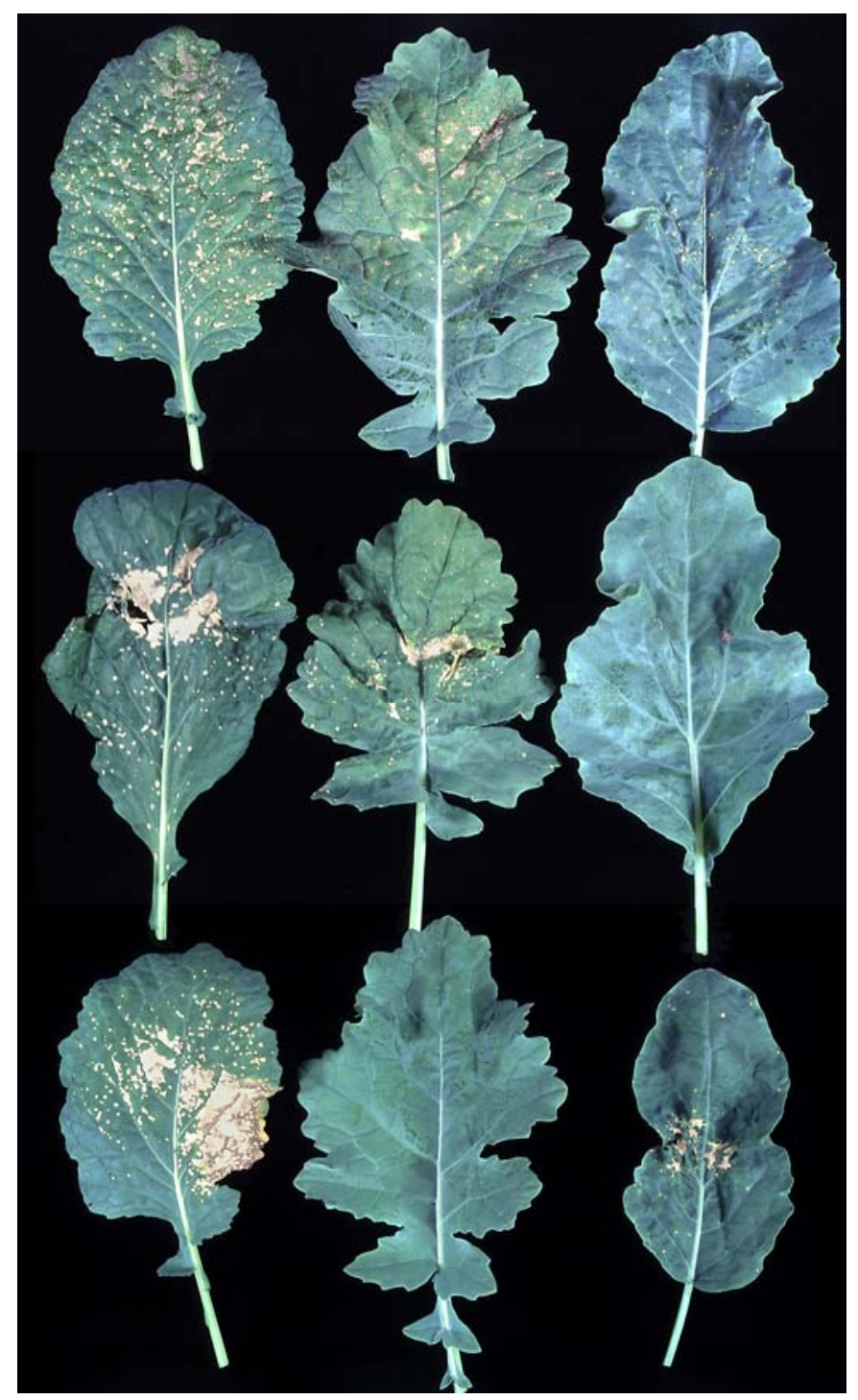

Fig. 5. Leaves (adaxial side) of Savoy cabbage cv. Wirosa $F_{1}$ (left), Brassica napus line Cobra 14R (center), and cauliflower cv. Miracle $\mathrm{F}_{1}$ (right) sprayinoculated with Xanthomonas campestris pv. raphani isolates HRI 8297 (bottom; 2 weeks after inoculation), 6520 (middle; 2 weeks after inoculation), and 8303 (top; 1 week after inoculation). therefore it seems unlikely that they would cause disease in these crops in commercial practice. However, it is likely that the isolates studied here would cause disease on members of the family Brassicaceae including different Brassica spp., radish, and some ornamental crops (e.g., wallflower) and, outside this family, on tomato. In very susceptible hosts, a water-soaked halo was frequently observed around the leaf spots. In weakly susceptible hosts, this was less frequent or was not observed. In these cases, to confirm that the lesions are a sign of pathogenicity and not just a hypersensitive response, the bacterial population in the lesions could be studied to check if the bacteria are actively multiplying.

$X$. vesicatoria and $X$. axonopodis pv. vesicatoria also cause spots on tomato and pepper, but not on Brassica spp. and radish, and the symptoms are distinct from those produced by the $X$. campestris leaf spot isolates.

We have confirmed that $X$. campestris pv. campestris can also cause spots on leaves of Brassica spp. (Fig. 1) and possibly on other crucifers, but not on other hosts like tomato. The symptoms are distinct from those caused by pv. raphani and generally progress toward typical vascular chlorotic black rot lesions. The reactions of the different $X$. campestris pv. campestris races when sprayed on the differential Brassica cultivars agreed with previous results obtained in wound inoculations (27), but the B. napus cv. Cobra line $14 \mathrm{R}$ seem to be more resistant in spray inoculations than in wound inoculations as it did not show symptoms when sprayed with two of the isolates (HRI 3811 [race 1] and HRI 3883 [race 5]).

Most leaf spot isolates studied here originated from $B$. oleracea, $B$. rapa, or radish, but one isolate from tomato was also identified as $X$. campestris pv. raphani (Table 3 ). Kuflu and Cuppels (10) also noticed that this isolate was distinct from $X$. vesicatoria and $X$. axonopodis pv. vesicatoria as it produced large spots on tomato and pepper and it was also highly pathogenic on radish and cabbage seedlings and they hypothesized that it was related to $X$. campestris pv. raphani. Jones et al. (5) also reported that an Xanthomonas isolate from tomato produced leaf spots and stem lesions on cabbage, and previously, Robbs (19) found that some isolates obtained in Brazil from tomato could infect pepper and cabbage and were probably $X$. vesicatoria (syn. campestris) pv. raphani.

Two isolates were obtained from $B$. oleracea seed tests and were originally considered nonpathogenic because, when inoculated on the secondary veins around the leaves using a pin or mouse-tooth forceps, they only produced small necrotic areas around the inoculation points (data not shown). Therefore, we suggest that routine pathogenicity tests of potential $X$. campestris isolates should be done on a brassica cultivar susceptible to both $X$. campestris pv. campestris and pv. raphani (e.g., Wirosa $\mathrm{F}_{1}$ ) and that some inoculation points should be done in the middle vein. Isolates that do not cause typical black rot symptoms, but cause dark sunken lesions can then be spray-inoculated to confirm their identification as $X$. campestris pv. raphani.

The inoculation results indicate that $X$. campestris pv. raphani can be divided into at least three races $(1,2$, and 3$)$ based on the differential reaction of Brassica, radish, and wallflower cultivars (Fig. 5). Races 1 and 3 appear to be the most common races in $B$. oleracea crops. Although the number of isolates studied is not

TABLE 3. Frequency of occurrence, host of origin, and geographical distribution of Xanthomonas campestris pv. raphani races among 25 isolates

\begin{tabular}{|c|c|c|c|}
\hline Race type & Host of origin (number of isolates) & Geographical origin (number of isolates) & $\begin{array}{c}\text { Total number } \\
\text { of isolates }\end{array}$ \\
\hline 1 & Brassica oleracea (5), Raphanus sativus (2), unknown (3) & $\begin{array}{l}\text { France (3), Southern Hemisphere (2), United States (2), } \\
\text { unknown (3) }\end{array}$ & 10 \\
\hline 2 & Brassica rapa (3), unknown (1) & Japan (2), United States (1), unknown (1) & 4 \\
\hline 3 & $\begin{array}{l}\text { Brassica oleracea (4), Brassica rapa (2), Raphanus sativus (1), } \\
\text { Lycopersicon esculentum (1), unknown (3) }\end{array}$ & $\begin{array}{l}\text { France (2), Japan (1), Canada (1), United States (4), } \\
\text { E. Asia (1), unknown (2) }\end{array}$ & 11 \\
\hline
\end{tabular}


large enough to reach a conclusion, there appeared to be no relationship between race and geographical origin of the isolates, but most race 2 isolates seem to have originated from the same host species, B. rapa (Table 3). A differential series is shown in Table 4 together with a postulated gene-for-gene model to explain the relationship between races and cultivars. The differential series only includes accessions that are $\mathrm{F}_{1}$ hybrids or uniform selections, and therefore should always give uniform reactions. It is only necessary to inoculate three Brassica cultivars to determine the pathogenicity and the race-type of potential $X$. campestris $\mathrm{pv}$. raphani; we recommend the use of $B$. oleracea cvs. Wirosa $F_{1}$ and Miracle $\mathrm{F}_{1}$ and a selection of B. napus cv. Cobra (Fig. 5), as all these accessions have also been previously included in the $X$. campestris pv. campestris differential series (27). The model presented is the simplest hypothesis involving the smallest number of genes (two matching gene pairs) necessary to explain the observed interactions. In this hypothesis, although not tested, gene homology was assumed for cultivars with the same pattern of reaction. The genes that confer resistance to races 1 and 2 were designated $\mathrm{R} 1$ and $\mathrm{R} 2$, respectively. The gene $\mathrm{R} 1$, present in B. napus, $B$. rapa, and $B$. juncea lines, confers resistance to race 1 isolates (with A1). This gene could have originated in the A genome of B. rapa. R2, present in B. oleracea cv. Miracle $\mathrm{F}_{1}$ and radish cv. Mino Early, confers resistance to race 2 isolates that have A2. This model provides a basis for understanding the interactions of races and cultivars and can be expanded if new races and differentials are identified.

rep-PCR-based genomic fingerprinting was used to assess the genetic diversity of the Xanthomonas leaf spot isolates and to compare them with representative isolates of $X$. campestris pv. campestris and related pathovars (Fig. 6). The results obtained from REP-, ERIC-, and BOX-PCR fingerprints were combined, as recommended by Rademaker et al. (16), to obtain more significant and consistent results. The results indicated that $X$. campestris pv. raphani is genetically distinct from $X$. campestris pv. campestris. In contrast, previous results of carbon source oxida-

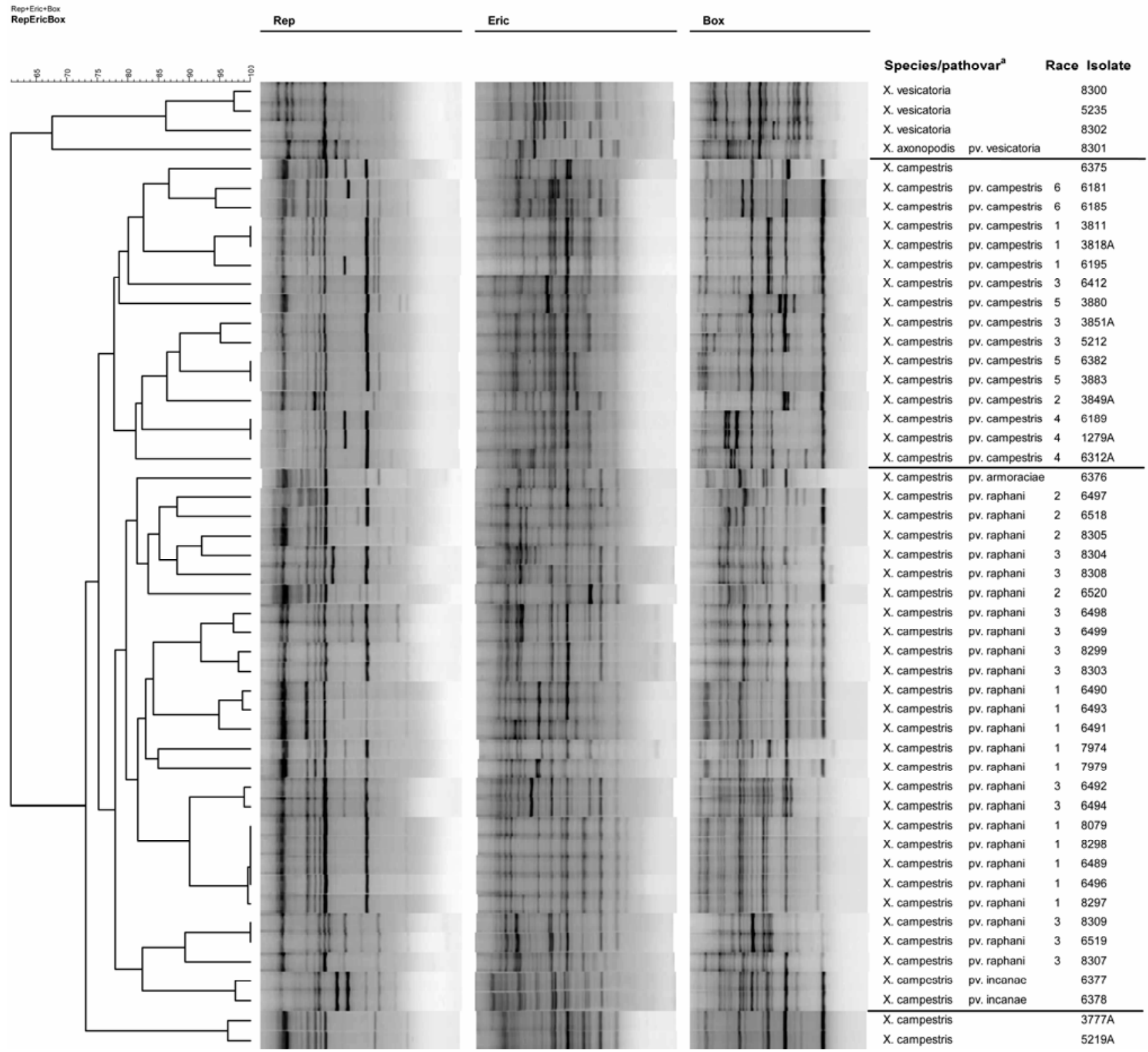

Fig. 6. Dendrogram of genetic similarity of 25 Xanthomonas campestris pv. raphani isolates together with 25 other Xanthomonas isolates. Similarities were calculated from the combined data of repetitive extragenic palindromic (REP), enterobacterial repetitive intergenic consensus (ERIC), and BOX primer sets using Dice's coefficient. The dendrogram was obtained using the unweighted pair-group method with arithmetic average method.

${ }^{\text {a }}$ The isolates were identified according to the results of this study and according to the results of the pathogenicity tests done previously by Vicente et al. (27). The isolate HRI 6375 from candytuft (Iberis sp.) and the isolates HRI 3777A and HRI 5219A from wallflower (Cheiranthus cheiri) should be included in new $X$. campestris pathovars. 
tion (Biolog) profiles, serological tests using monoclonal antibodies, restriction fragment length polymorphism (1), BOX-PCR alone (31), and even REP-, ERIC-, and BOX-PCR combined (18) failed to distinguish the two pathovars. Although $X$. campestris pv. raphani and $X$. campestris pv. campestris isolates are highly variable even within each race, some groups were formed. Alvarez et al. (1) also reported that isolates that cause black rot and isolates that cause leaf spots were both genetically heterogeneous. The clusters formed seemed to be more related to the races than to the host or geographical origin of the isolates. These findings contrast with results obtained by Massomo et al. (13) and Tsygankova et al. (23) that indicated that geographical origin was a major factor for $X$. campestris pv. campestris genetic diversity.

The results of our genetic diversity study showed that the $X$. campestris isolates from wallflower are quite distinct from $X$. campestris pv. campestris and $X$. campestris pv. raphani. We have showed previously that they cause a vascular disease of wallflower (27). These isolates should not be included in X. campestris pv. campestris, and should be considered a distinct (new) pathovar. Isolate HRI 6375 (NCPPB 347) from candytuft was not included in the $X$. campestris pv. raphani cluster (that also included the horseradish isolate), but was closer to some $X$. campestris pv. campestris isolates. Rademaker et al. (18) also noticed

TABLE 4. Postulated gene-for-gene model to explain the relationship between different hosts and races of Xanthomonas campestris pv. raphani

\begin{tabular}{|c|c|c|c|c|}
\hline \multirow[b]{3}{*}{ Differential cultivars or accessions ${ }^{\mathrm{a}}$} & \multirow{3}{*}{$\begin{array}{l}\text { Resistance } \\
\text { (R) genes }\end{array}$} & \multicolumn{3}{|c|}{ Races/avirulence (A) genes $^{\mathrm{b}}$} \\
\hline & & 1 & 2 & 3 \\
\hline & & A1 & A2 & \\
\hline $\begin{array}{l}\text { Wirosa } \mathbf{F}_{1} \text {, selection of PI } 199947, \\
\text { radish cv. French Breakfast 3, } \\
\text { tomato cv. Moneymaker }\end{array}$ & & + & + & + \\
\hline $\begin{array}{l}\text { Cobra 14R, Just Right Hybrid } \\
\text { Turnip, Florida Broad Leaf Mustard }\end{array}$ & R1 & - & + & + \\
\hline Miracle $\mathbf{F}_{\mathbf{1}}$, radish cv. Mino Early & $\mathrm{R} 2$ & + & - & + \\
\hline
\end{tabular}

that the isolate from candytuft and the isolate from horseradish had distinct fingerprint profiles. This isolate causes a vascular disease in candytuft and was also pathogenic in some radish plants (27), but is not pathogenic on Brassica spp. or horseradish. Therefore, this isolate should not be included in and should not be designated as the pathotype strain of $X$. campestris pv. armoraciae, and should be considered a distinct (new) pathovar. The isolates from stock were included in the $X$. campestris pv. raphani cluster. These isolates cause a vascular disease of stock (27) and are included in a separate pathovar (X. campestris pv. incanae). We were unable to confirm the existence of $X$. campestris pv. armoraciae; the single isolate from horseradish was included in the $X$. campestris pv. raphani cluster, but does not appear to be pathogenic. The current information on the host range of the $X$. campestris pathovars is summarized in Table 5.

A major problem of many previous studies on the diversity of $X$. campestris isolates was the lack of reliable, pathogenic typestrains that represent isolates that cause vascular disease in Brassica spp. and other crucifers, and type-strains of isolates that only cause leaf spots and petiole and stem sunken lesions. Our work has shown that the type-strain of $X$. campestris pv. raphani (HRI 3883, NCPPB 1946) does not cause the leaf spot disease described by White (28) (Fig. 1); this isolate was previously shown to correspond to race 5 of $X$. campestris pv. campestris (27). We propose that isolates HRI 6490 (race 1), HRI 8305 (race 2), and HRI 6519 (race 3) should be designated as new race-type strains of $X$. campestris pv. raphani. As race 3 seems to be the most common race, we propose that isolate HRI 6519 from radish should be designated as the neopathotype strain. These strains together with the proposed gene-for-gene model should assist in genetic and pathogenic studies of Xanthomonas spp. and could be used for the selection of resistant material for breeding programs. Our model needs to be further supported by detailed genetic and molecular data from both the host and the pathogen to be fully validated.

\section{ACKNOWLEDGMENTS}

This work was carried out under a plant health license (PHL 275/4843) from and was supported by the Department for Environment, Food and Rural Affairs (Defra) of the United Kingdom. We thank M. Asma (Bejo Zaden, The Netherlands), H. Bouzar (Sakata Seed America, Inc., Salinas,

TABLE 5. Host range of Xanthomonas campestris pathovars from cruciferous hosts based on studies by McCulloch (14), White (28), Vicente et al. (27), and the present study

\begin{tabular}{|c|c|c|c|c|c|c|c|c|}
\hline \multirow[b]{2}{*}{ Pathovar } & \multirow[b]{2}{*}{ Host of origin } & \multicolumn{7}{|c|}{ Pathogenicity to ${ }^{\mathrm{a}}$} \\
\hline & & $\begin{array}{l}\text { Cabbage cv. } \\
\text { Wirosa } \\
\text { (Brassica } \\
\text { oleracea) }\end{array}$ & $\begin{array}{l}\text { Radish } \\
\text { (Raphanus } \\
\text { sativus) }\end{array}$ & $\begin{array}{c}\text { Stock } \\
\text { (Matthiola } \\
\text { incana) }\end{array}$ & $\begin{array}{l}\text { Wallflower } \\
\text { (Cheiranthus } \\
\text { cheiri) }\end{array}$ & $\begin{array}{l}\text { Candytuft } \\
\text { (Iberis sp.) }\end{array}$ & $\begin{array}{l}\text { Horseradish } \\
\text { (Armoracia } \\
\text { rusticana) }\end{array}$ & $\begin{array}{l}\text { Tomato cv. } \\
\text { Moneymaker } \\
\text { (Lycopersicon } \\
\text { esculentum) }\end{array}$ \\
\hline $\begin{array}{l}\text { X. campestris pv. } \\
\text { campestris }^{\mathrm{b}}\end{array}$ & $\begin{array}{l}\text { Various (Brassica sp., Raphanus } \\
\text { sativus, Sinapis arvensis, and other } \\
\text { cruciferous weeds) }\end{array}$ & $v+$ & $\mathrm{v}+/-$ & - & - & - & - & - \\
\hline $\begin{array}{l}\text { X. campestris pv. } \\
\text { incanae }\end{array}$ & Matthiola sp. & - & - & $v+$ & - & - & $\mathrm{nt}$ & - \\
\hline X. campestris $^{\mathrm{c}}$ & Cheiranthus cheiri & - & - & - & $v+$ & - & $\mathrm{nt}$ & - \\
\hline X. campestris ${ }^{\mathrm{d}}$ & Iberis $\mathrm{sp}$. & - & $v+/-$ & - & - & $v+$ & - & - \\
\hline $\begin{array}{l}X . \text { campestris } \mathrm{pv} . \\
\text { raphani } \\
X . \text { campestris }\end{array}$ & $\begin{array}{l}\text { Various (Brassica spp., Raphanus } \\
\text { sativus, Lycopersicon esculentum) }\end{array}$ & $1 \mathrm{~s}+$ & $1 \mathrm{~s}+/-$ & - & $1 \mathrm{~s}+/-$ & $1 \mathrm{~s}+/-$ & ls $(+)$ & $1 \mathrm{~s}+$ \\
\hline pv. armoraciae $^{\mathrm{f}}$ & Armoracia rusticana & 1s $(+)$ & - & - & - & - & 1s + & - \\
\hline
\end{tabular}

${ }^{a}$ v, vascular infection; 1s, leaf spot symptoms; +, compatible interaction (susceptibility); (+), weakly pathogenic; -, incompatible interaction (resistance); +/-, variable reaction between and/or within cultivars; and nt, not tested

${ }^{\mathrm{b}}$ Some of these isolates were previously included in X. campestris pv. aberrans (HRI 3880) and X. campestris pv. raphani (HRI 3883 ).

${ }^{\mathrm{c}}$ Isolates HRI 3777A and HRI 5219A previously included in X. campestris pv. campestris.

${ }^{\mathrm{d}}$ Isolate HRI 6375 previously included in X. campestris pv. armoraciae

e Postulated based on the description of White (28) and results of the present study.

${ }^{f}$ Postulated based on the description of McCulloch (14). The existence of this pathovar has not been confirmed (27); the only isolate from horseradish (HRI 6376) studied here was nonpathogenic and failed to produce leaf spots on either horseradish or the other hosts tested. 
CA), D. A. Cuppels (Agriculture and Agri-Food Canada, Ontario, Canada), J. P. Damicone (Oklahoma State University, Stillwater), and K. Tamura (Institute of Molecular and Cellular Biosciences, Tokyo, Japan) for supplying some of their isolates; and B. Keenan from Bio-Rad Laboratories, Ltd., for the use of Fingerprinting II.

\section{LITERATURE CITED}

1. Alvarez, A. M., Benedict, A. A., Mizumoto, C. Y., Hunter, J. E., and Gabriel, D. W. 1994. Serological, pathological and genetic diversity among strains of Xanthomonas campestris infecting crucifers. Phytopathology 84:1449-1457.

2. Black, L. L., and Machmud, M. 1983. Xanthomonas leaf spot of crucifers. Page 126 in: Int. Cong. Plant Pathol., 4th ed., Melbourne, Australia.

3. Bradbury, J. F. 1986. Guide to Plant Pathogenic Bacteria. CAB International, Slough, UK.

4. Feltham, R. K. A., Power, A. K., Pell, P. A., and Sneath, P. H. A. 1978. A simple method for the storage of bacteria at $-76^{\circ} \mathrm{C}$. J. Appl. Bacteriol. 44:313-316.

5. Jones, J. B., Bouzar, H., Stall, R. E., Almira, E. C., Roberts, P. D., Bowen, B. W., Sudberry, J., Strickler, P. M., and Chun, J. 2000. Systematic analysis of xanthomonads (Xanthomonas spp.) associated with pepper and tomato lesions. Int. J. Syst. Evol. Microbiol. 50:1211-1219.

6. Jones, J. B., Stall, R. E., and Bouzar, H. 1998. Diversity among xanthomonads pathogenic on pepper and tomato. Annu. Rev. Phytopathol. $36: 41-58$

7. Kamoun, S., Kamdar, H. V., Tola, E., and Kado, C. I. 1992. Incompatible interactions between crucifers and Xanthomonas campestris involve a vascular hypersensitive response: Role of the hrpX locus. Mol. PlantMicrobe Interact. 5:22-33.

8. King, E. O., Ward, M. K., and Raney, D. R. 1954. Two simple media for the demonstration of pyocyanin and fluorescein. J. Lab. Clin. Med. 44:301-307.

9. Kogan, S. C., Doherty, M., and Gitschier, J. 1987. An improved method for prenatal diagnosis of genetic diseases by analysis of amplified DNA sequences. Application to Hemophilia A. New Engl. J. Med. 317:985-990.

10. Kuflu, K. M., and Cuppels, D. A. 1997. Development of a diagnostic DNA probe for xanthomonads causing bacterial spot of peppers and tomatoes. Appl. Environ. Microbiol. 63:4462-4470.

11. Louws, F. J., Rademaker, J. L. W., and de Bruijn, F. J. 1999. The three Ds of PCR-based genomic analysis of phytobacteria: Diversity, detection, and disease diagnosis. Annu. Rev. Phytopathol. 37:81-125.

12. Lyons, N. F., and Taylor, J. D. 1990. Serological detection and identification of bacteria from plants by the conjugated Staphylococcus aureus slide agglutination test. Plant Pathol. 39:584-590.

13. Massomo, S. M. S., Nielsen, H., Mabagala, R. B., Mansfeld-Giese, K., Hockenhull, J., and Mortensen, C. N. 2003. Identification and characterisation of Xanthomonas campestris pv. campestris strains from Tanzania by pathogenicity tests, Biolog, rep-PCR and fatty acid methyl ester analysis. Eur. J. Plant Pathol. 109:775-789.

14. McCulloch, L. 1929. A bacterial leaf spot of horseradish caused by Bacterium campestris var. armoraciae, n. var. J. Agric. Res. 38:269-287.
15. Poplawsky, A. R., and Chun, W. 1995. Strains of Xanthomonas campestris pv. campestris with atypical pigmentation isolated from commercial crucifer seeds. Plant Dis. 79:1021-1024.

16. Rademaker, J. L. W., Hoste, B., Louws, F. J., Kersters, K., Swings, J., Vauterin, L., Vauterin, P., and de Bruijn, F. J. 2000. Comparison of AFLP and rep-PCR genomic fingerprinting with DNA- DNA homology studies: Xanthomonas as a model system. Int. J. Syst. Evol. Microbiol. 50:665677.

17. Rademaker, J. L. W., Louws, F. J., and de Bruijn, F. J. 1998. Characterization of the diversity of ecologically important microbes by rep-PCR genomic fingerprinting. Pages 1-27 in: Molecular Microbial Ecology Manual. A. D. L. Akkermans, J. D. van Elsas, and F. J. de Bruijn, eds. Kluwer Academic Publishers, Dordrecht, The Netherlands.

18. Rademaker, J. L. W., Louws, F. J., Schultz, M. H., Rossbach, U., Vauterin, L., Swings, J., and de Bruijn, F. J. 2005. A comprehensive species to strain taxonomic framework for Xanthomonas. Phytopathology 95:10981111.

19. Robbs, C. F. 1961. Phytopathogenic bacteria in Brazil. Rev. Appl. Mycol. 40:75.

20. Roberts, S. J., Brough, J., Everett, B., and Redstone, S. 2004. Extraction methods for Xanthomonas campestris pv. campestris from brassica seed. Seed Sci. Technol. 32:439-453.

21. Sahin, F., and Miller, S. A. 1997. A new pathotype of Xanthomonas campestris pv. armoraciae that causes bacterial leaf spot of radish. Plant Dis. 81:1334.

22. Tamura, K., Takikawa, Y., Tsuyumu, S., and Goto, M. 1994. Bacterial spot of crucifers caused by Xanthomonas campestris pv. raphani. Ann. Phytopathol. Soc. Jpn. 60:281-287.

23. Tsygankova, S. V., Ignatov, A. N., Boulygina, E. S., Kuznetsov, B. B., and Korotkov, E. V. 2004. Genetic relationships among strains of Xanthomonas campestris pv. campestris revealed by novel rep-PCR primers. Eur. J. Plant Pathol. 110:845-853.

24. Vauterin, L., Hoste, B., Kersters, K., and Swings, J. 1995. Reclassification of Xanthomonas. Int. J. Syst. Bacteriol. 45:472-489.

25. Versalovic, J., Koeuth, T., and Lupski, J. R. 1991. Distribution of repetitive DNA-sequences in eubacteria and application to fingerprinting of bacterial genomes. Nucleic Acids Res. 19:6823-6831.

26. Versalovic, J., Schneider, M., de Bruijn, F. J., and Lupski, J. R. 1994. Genomic fingerprinting of bacteria using repetitive sequence-based polymerase chain reaction. Methods Mol. Cell. Biol. 5:25-40.

27. Vicente, J. G., Conway, J., Roberts, S. J., and Taylor, J. D. 2001. Identification and origin of Xanthomonas campestris pv. campestris races and related pathovars. Phytopathology 91:492-499.

28. White, H. E. 1930. Bacterial spot of radish and turnip. Phytopathology 20:653-662.

29. Williams, P. H. 1980. Black rot: A continuing threat to world crucifers. Plant Dis. 64:736-742.

30. Wilson, E. E., Zeitoun, F. M., and Fredrickson, D. L. 1967. Bacterial phloem canker, a new disease of Persian walnut trees. Phytopathology $57: 618-621$

31. Zhao, Y., Damicone, J. P., Demezas, D. H., Bender, C. L., and Zhao, Y. F. 2000. Bacterial leaf spot diseases of leafy crucifers in Oklahoma caused by pathovars of Xanthomonas campestris. Plant Dis. 84:1008-1014. 